\title{
Ichneumonidae (Hymenoptera) new to Finland. IV
}

\author{
Reijo Jussila
}

Jussila, R. 1996: Ichneumonidae (Hymenoptera) new to Finland. IV. Entomol. Fennica 7: 95-98.

Five ichneumonids new to Finland are reported: Syrphoctonus megaspis (Thomson), Woldstedtius holarcticus (Diller), Diplazon pallicoxa Manykian, Chorinaeus flavipes Bridgman and Trieces dinianae Aeschlieman.

Reijo Jussila, Krouvintie 92, FIN-21330 Paattinen, Finland

Received 22 November1994, accepted 15 May 1995

\section{Diplazontinae}

Syrphoctonus megaspis (Thomson, 1890)

Homoporus megaspis Thomson 1890: 1516, . . Homocidus megaspis (Thomson). Morley 1914: 130, ․ Diplazon megaspis (Thomson). Beime 1941: 693, ơo. Homotropus megaspis (Thomson). Dasch 1964: 100. Syrphoctonus megaspis (Thomson). Fitton 1982: 42.

Four females have been found as a new species to the Finnish fauna: $A l$ : Finström, Husö 670:10 9.IX.1978 (mixed lamp, R. Jussila leg.), Ab: Kaarina, Kuusisto 675: 23 9.IX.1980 (luxuriant growth grass, R. Jussila leg.), Mynämäki, Pahnassuo of Kalela 675:23 9.IX.1978 (pine bog, R. Jussila leg.), and St: Pori, Reposaari 684:20 28.VII.1969 (mixed lamp, V. Lauro leg.). The species has earlier been found in Germany (Schmiedeknecht 1926) and Ireland (Beirne 1941).

Among the Finnish Syrphoctonus species megaspis most dosely resembles S. pictus (Gravenhorst, $1829)$ but it is larger (6-7 mm long, length of pictus is $4-6 \mathrm{~mm}$ ) and it has more profuse pale markings (e.g. the scutellum has pale margins at the sides and apex, and the large facial path meets the yellow clypeus). For more details, see Beirne (1941).

\section{Woldstedtius holarcticus (Diller, 1969)}

Syrphoctonus holarcticus Diller 1969: 546, o. Woldstedtius holarcticus (Diller). Kasparyan 1981: 506.
1 Q has been found in Al: Finström, Husö 670:10 4.VIII.1978 (mixed lamp, R. Jussila leg.), 1 \& $A b$ : Houtskari, Hyppeis 669:19 VII.1988 (mixed lamp, H. Bruun leg.), 1 \& Sauvo, Karinkorva of Karuna 669:25 21.VII.1966 in a meadow (R. Jussila leg.), 2 of Ka: Virolahti 672:53 21.VII. 1975 (mixed lamp, R. Jussila leg), 1 o St: Pori, Reposaari 684:20 4.VIII.1969 (mixed lamp, V. Lauro leg.), $E H$ : Lempäälä, Mäyhäniemi 680:32 1968 (mixed lamp, O.Sotavalta leg.), and 1 o Oa: Ilmajoki 697:27 22.VII.1988 (V.-M. Mukkala. leg.).

This species, new to the fauna of Finland, has previously been found in Central Europe, Russia, India and North America (Diller 1969 and 1980, Kasparyan 1981).

Woldstedtius holarcticus resembles most of all W. flavolineatus (Gravenhorst, 1829) but its middle and hind coxae are black with lemon yellow apex and often with a lemon yellow longitudinal streak (Fig. 1), and its hind coxae are black. The hind tibiae of holarcticus are proximally far yellow, and the hind tibiae and tarsi thin (Fig. 3). The head of holarcticus is broad and only a little high, and the face rather flat (Fig. 5). In flavolineatus the middle and hind coxae are reddish (Fig. 2), the hind tibiae only somewhat yellow basal, its hind tibiae and tarsi are ticker, its head is not so broad (Fig. 4) and its face is a little raised. (Fig. 6). The face of $S$. holarcticus has been scored in Fig. 7. For more details, see Diller (1969). 

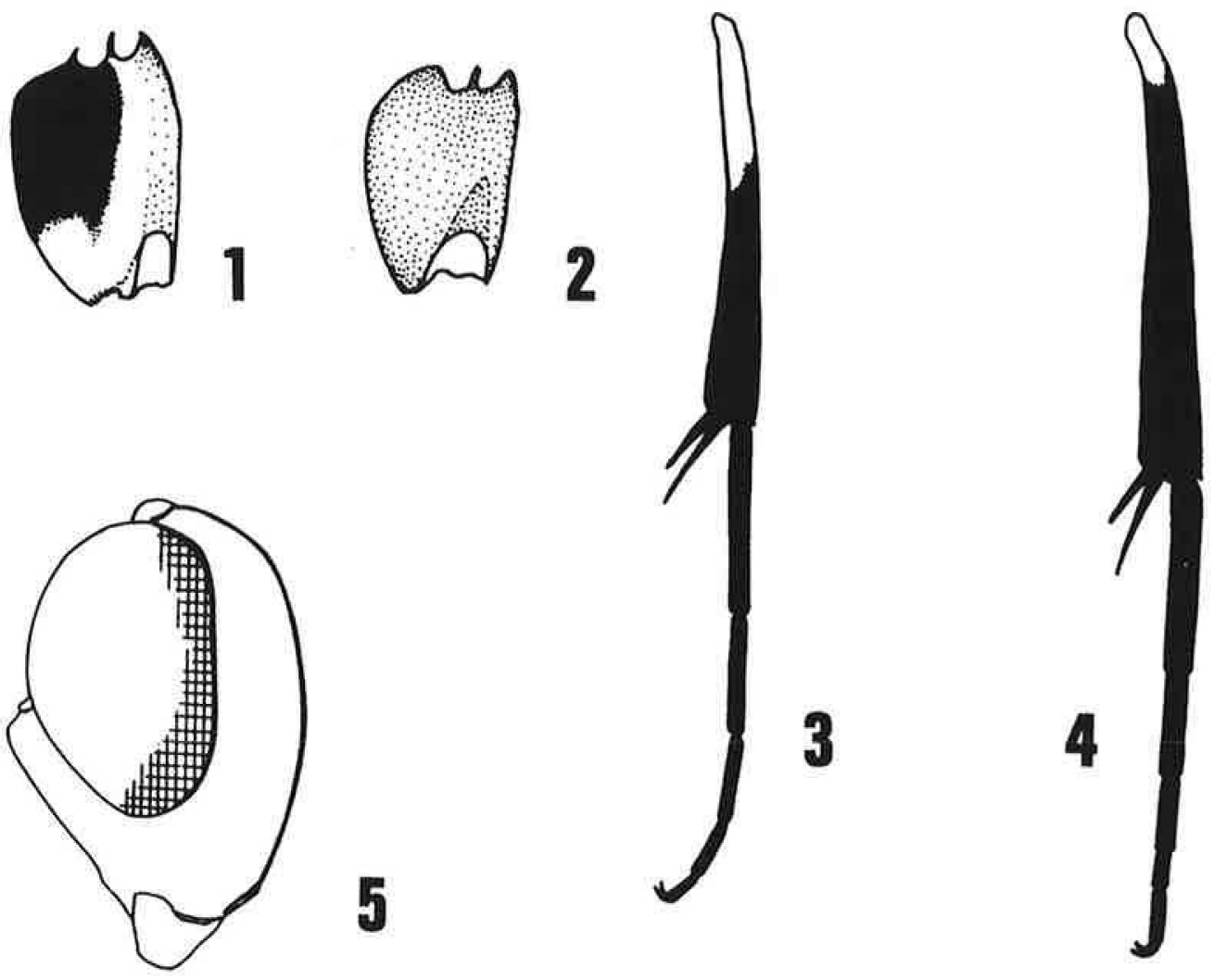

5
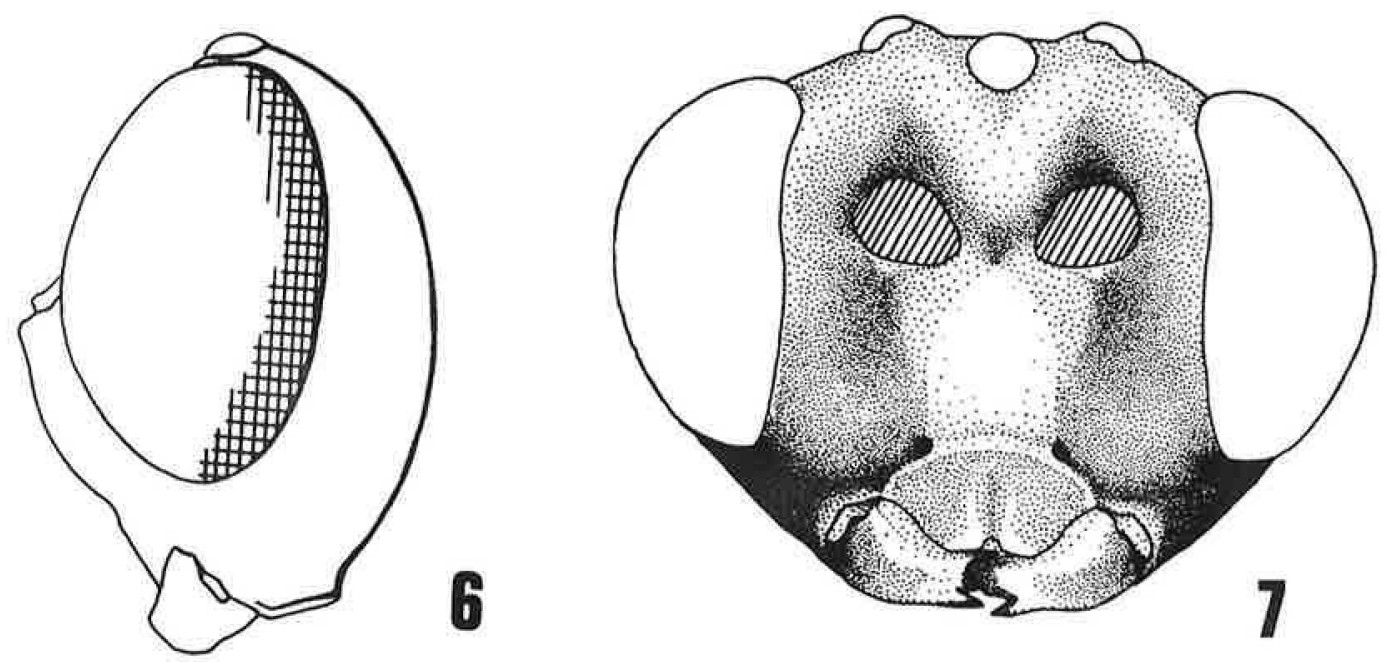

Figs. 1, 3, 5 and 7. Woldstedtius holarcticus (Diller), and Figs. 2, 4 and 6. Woldstedtius flavolineatus (Gravenhorst). - 1. and 2. middle coxa; 3 and 4. hind tibia and tarsi; 5 . and 6. head, in sinistral view; 7. face, in front view. 

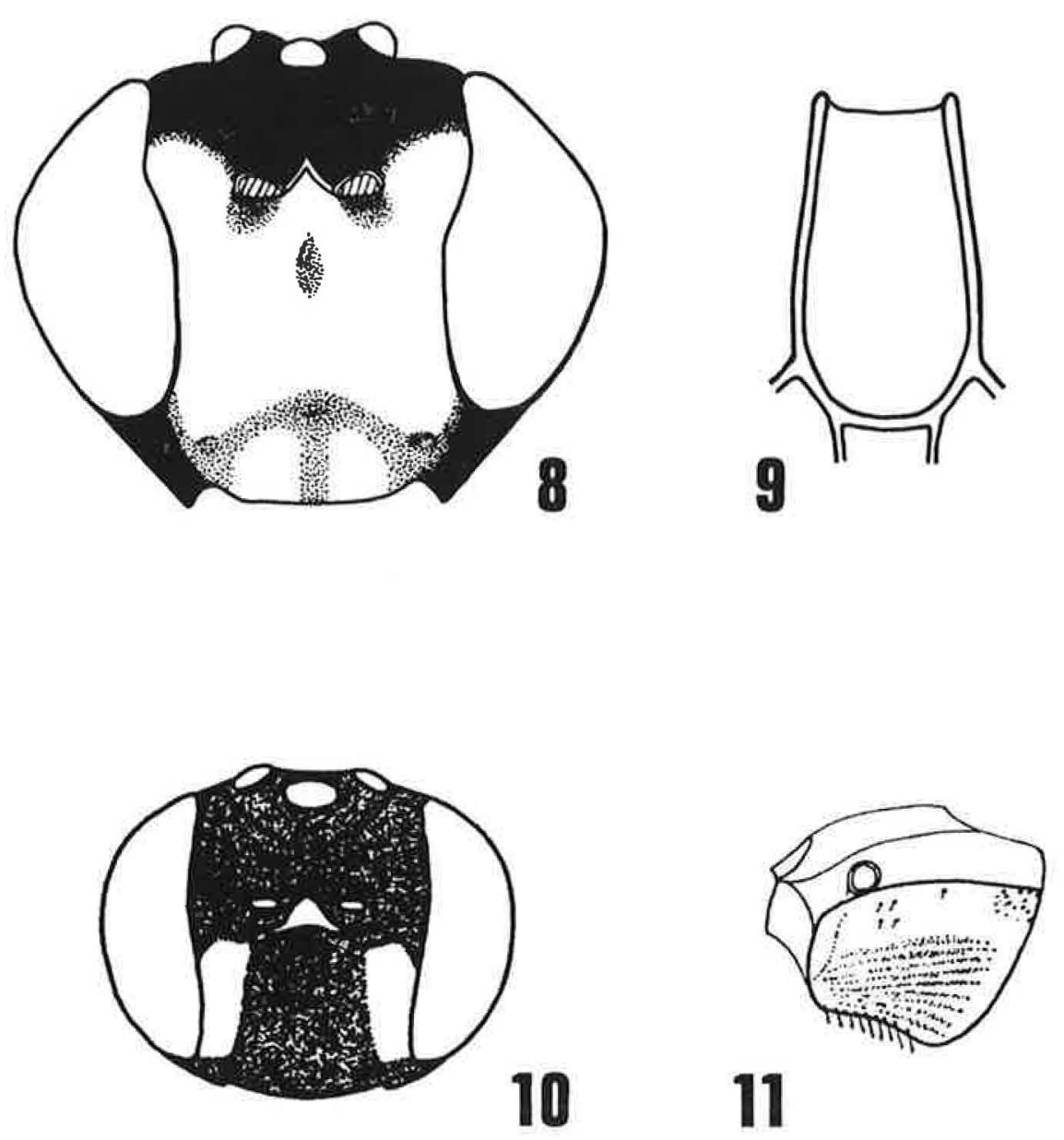

Figs. 8-9. Chorinaeus flavipes Bridgman. - 8. face, in front view; 9. fused areola and basal areola of propodeum, in dorsal view. Figs. 10-11. Trieces dinianae Aeschlieman. -10 . face, in front view; 11 . propodeum, in sinistral view.

\section{Diplazon pallicoxa Manukyan, 1987}

Diplazon pallicoxa Manukyan 1987: 70, ơo

One female has been found in $A b$ : Sauvo, Karinkorva of Karuna 669:25 11.VIII.1985 from vegetation by the side of a road (R. Jussila leg.). This species, new to Finland, has previously been found at least in Russia (e.g. from St. Petersburg) and Armenia (Manukyan 1987).

The best identification marks of Diplazon pallicoxa are its yellowish hind coxae, weak carinae of the propodeum and apical missing carinae of the 1st tergite. Orbital streaks in pallicoxa are broad reaching as far as the mandibles and widening downward, the face is weakly chagrined and the anten- nae have relatively long hairs. For more details, see Manukyan (1987).

\section{Metopiinae}

Chorinaeus flavipes Bridgman, 1881

Chorinaeus flavipes Bridgman, 1881: 165; Kusigemati 1969 and 1971, 070.

One male specimen has been found in $A b$ : Turku, Paattinen 672:24 15.VI.1985 in grass (Jarkko Jussila leg.). The species is new to the Finnish fauna and it is the first find of the male sex in Europe. It has earlier been found in Sweden, Great Britain 
(Aeschlieman 1975) and Japan (Kusigemati 1971).

This species is easily recognisable by its yellowish front and middle legs and hind tibiae. Its malar space is longer than the basal width of the mandible (Fig. 8), the mandible is about 1.6 times as long as the basal width, the fused areola and basal areola of the propodeum is rather parallelsided (Fig. 9), and the tarsal claws are pectinate. For more details of Ch. flavipes, see Aeschlieman 1979 and of the male, see Kusigemati (1967).

\section{Trieces dinianae Aeschlieman, 1973}

Trieces dinianae Aeschlieman 1973: 982, $0^{7} \mathrm{O}$.

$10^{7}$ has been found in $S b$ : Varpaisjärvi 702:54 16.VI.1988 and 3 oo in Kn: Kuhmo, Ulvinsalo 710:66 8.VII.1980. All specimens were collected from pine bogs (R. Jussila leg). This species has earlier been found in French and the Altai mountains (Tolkanitz 1981).

Trieces dinianae is easily recognisable by the colouring of the face (Fig. 10) and the extremely wide stigma of the propodeum (Fig. 11). For more details, see Aeschlieman (1973).

\section{References}

Aeschlieman, J.-P. 1973: Révision des espéces ouest-paléarctiques du genre Trieces (Hymenoptera, Ichneumonidae). — Ann. Soc. entomol. France (N.S.) 9: 975-987.

- 1975: Révision des espèces ouest-paléarctiques du genre Chorinaeus Holmgren (Hymenoptera, Ichneumonidae) - Ann. Soc. entomol. France (N.S.) 11: 723-744.

Beime, B. P. 1941: British species of Diplazontini (Bassini auctt.) with a study of the genital and postgenital abdominal sclerites in the male (Hym.: Ichneum.) - Transact. R. Entomol. Soc. London 91: 661-712.
Bridgman, J. B. 1881: Some additions to Mr. Marshall's catalogue of British Ichneumonidae. - Transact. R. Entomol. Soc. London 1881: 143-168.

Dasch, C. E. 1964: Ichneumon-flies of America north of Mexico. - Mem. Amer. Entomol Inst. 3, 304 pp.

Diller, E. H. 1969: Beitrag zur Taxonomie der Gattung Syrphoctonus Foerster mit Beschreibung einer neuen holarktischen Art. - Acta. entomol. Mus. natl. Pragae 38: 545-552.

- 1980: Die in Indien vorkommenden Taxa der Gattung Syrphoctonus Foerster, 1868 (Hymenoptera, Ichneumonidae, Diplazontinae). — Entomofauna 1980: 29-36.

Fitton, M. G. 1982: A catalogue and reclassification of the Ichneumonidae (Hymenoptera) described by C.G. Thomson. - Bull. Brit. Mus. (Nat. Hist.) 45 (1), 1-119.

Kasparyan, D. 1981: Diplazontinae. - In: Kasparyan, D. (ed.), Opredeliteli Faune SSSR 129 (A guide to the insects of the European part of USSR III. Hymenoptera, Ichneumonidae), 500-506.

Kusigemati, K. 1967: On the Japanese species of the genus Chorinaeus Holmgren, with descriptions of five new species (Hymenoptera: Ichneumonidae). - Ins. Matsumur. 30: 17-27.

- 1971: Taxonomic studies on the subfamily Metopiinae of Japan (Hymenoptera: Ichneumonidae). - Mem. Fac. Agric., Kagoshima Univ. 8: 205-298.

Manukyan, A. R. 1989: [On the systematics of ichneumonids of the genus Diplazon Nees (Hymenoptera, Ichneumonidae) of the fauna of the USSR.] - In: Storozheva \& Kusakin (eds.), [New data on the systematics of insects of the Soviet Far East]. Acad. Sci. USSR, Vladivostock, 66-72.

Morley, C. 1914: A revision of the Ichneumonidae, based on the collection in the British Museum. With descriptions of new genera and species. Tribes Pimplides and Bassides. - London, X and 148 pp.

Schmiedeknecht, O. 1911-1927: Opuscula Ichneumonologica 5. Tryphoninae. - Blankenburg i Thür., 2275-3570.

Thomson, C. G. 1890: Öfversigt af arterna inom slägtet Bassus (Fab.). - In Thomson, C. G. (ed.), Opuscula Entomologica 14 (43): 1459-1525.

Tolkanitz, V. I. 1981: Metopiinae. - In: Kasparyan, D. (ed.): Oprediteli Faune SSSR 129 (A guide to the insects of the European part of USSR III. Hymenoptera, Ichneumonidae), 451-476. 